\title{
The Effect of English Teaching Material Using Total Physical Response (TPR) Based Character Education in Elementary School
}

\author{
Rindilla Antika ${ }^{1, *}$ Elsy Melia Syari ${ }^{1}$ \\ ${ }^{I}$ Department of Elementary School Teacher Education, STKIP Nasional, Padang Pariaman, Indonesia \\ ${ }^{2}$ Department of Elementary School Teacher Education, STKIP Nasional, Padang Pariaman, Indonesia \\ *Corresponding author. Email: dillarindilla@ gmail.com
}

\begin{abstract}
This research aimed to examine the effectivenes of the English teaching material oriented to character-based through the TPR as a learning model in improving students' English ability. This research employed a pre-experimental research with the design one group pretest-postest. The improvemet was measured through N-Gain calculation. Subject of the research was the fifth-grade students, as many as 20 students, in one of private elementary school in Pariaman City. The data was collected through tests and observation cheklist. The result of this research showed that the English teaching material was effective in improving students' English ability. Thus, it was also effective to instill students' values in learning process. In conclusion, the implementation of English teaching material intensified students' hardskills and softskills.
\end{abstract}

Keywords: Character education, English teaching material, TPR.

\section{INTRODUCTION}

English as a world language had significant roles to be taught and studied at each level of education started from primary education to higher education. In Indonesia education system, English was taught as local content in primary school curriculum which meant English teaching could be in the form of mandatory content and local content [1]. English teaching in primary school had been implemented since the 1994 curriculum to the 2013 curriculum. The aimed of English teaching and learning at elementary school based on the regulation of the Minister of National Education No. 22 of 2006 was to develop comuunication competence in a limited oral form to accompany action (language accompanying action ) in the school contexts and to have an awareness of the importance of English in a global society to improve the nation's competitiveness [2].

The changes of curriculum in Indonesia's education system especially the primary school curriculum affected the essentials of learning English. In implementation of the 1994 curriculum, English as local content was utilized as one of compulsory subject which caused almost all primary school both private and public employed English as their local content to be taught [3]. However, in the 2013 curriculum, English was taught and studied as the additional local subject. So, it caused English was rarely encountered or taught in elementary school. It became a polemic in itself considering the development of the technology and globalization era in which English was required.

Based on preliminary observation at one of private elementary school in Pariaman City, it showed that the English learning seems stiff and lacklutre. The teaching of English was focused on the memorization method where the children were asked to write and memorize the vocabulary given by the teacher. Moreover, in the teaching and learning process, the teachers lack of media and learning resource. Teachers also seem to have difficulty in determining teaching materials because learning resources or curriculum guidelines are not available. This is in line with the results of research conducted by Zein who stated that the difficulties faced by elementary teachers in English language teaching are the unavailability of curriculum guidance, lack of resources and subject matter, and inadequate teacher quality in English language teaching [4][5]. 
In addition, the students also seem to lack of understanding, look less excited, and have difficulty in sepaking English because the teachers do not provide teaching materials. The students also do not have English students' book which create the learning process is teacher-centerred. Consequently, the English language skills of elementary students have not shown satisfactory results.

In order to overcome these problems, it is necessary to develop teaching materials that can be a guideline and can attract students' interest to learn in order to improve their English ability. The development of teaching materials that will be carried out is the development of English teaching materials that use the TPR as a learning model. TPR learning model is a suitable and effective learning model in motivating and improving students' ability to learn [6]. The TPR method is a method of learning English which learning accentuates activities directly related to physical activities and movements. In addition, in the implementation of the 2013 curriculum, the main focus is character education. It is similar with the aims of national education objectives which to form a student who has a strong character and intelegent [7] in a society. ). Character education teaching is integrated in the teaching of other subjects so that students do not realize that they are being given the teaching of moral values and character. Thus, a teaching material oriented to character education is required.

This study aims to find out the effectiveness of developing English teaching materials using a character education-oriented an $\mathrm{d}$ the Total Physical Response (TPR) model. It is because there is no teaching material that integrates both hard skills and soft skills. It is expected that the English teaching material developed can improve both students' English ability and their character values. Furthermore, the result of this study could be useful for teachers, students, and other researchers. The benefits of this research for teachers, it can be one of the guidelines in carrying out English learning; the benefits for students, it can be a source of independent English learning, and the benefits for other researchers that it can be one of the references in carrying out further research related to the TPR model and character education.

\section{METHOD}

\subsection{Subject and Steps of the Research}

Subject of this research was the fifth-grade students in the private elementary school in Pariaman City with a sample of 20 students. In conducting this reseacrch, the pre-test was conducted at the beginning of the study and given to the students in form of multiple choice and fillin the blank questions to evaluate their ability in learning English. Then, a process of learning using English teaching material based character education and using Total Physical Response (TPR) learning model was given. After implementing the English teaching material developed, they were given a post-test. Before conducted the pre-test and the post-test, the questions have been tested. Besides that, students' characters also being observed. The character observed were (1) confident, (2) responsibility, (3) hardwork, and (4) creative.

\subsection{Research Design}

The design of this research was pre-experimental research empolyed One Group Pretest-Posttest Design. It was chosen to identify the product developed effectivenes [8]. It is illusrated in Figure 1.

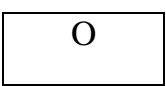

Pre-test

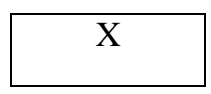

Treatmen

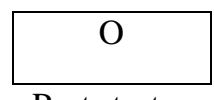

Post- test
Figure 1. Research Design

The figure 1 showed how the research was done. $\mathrm{O}$ represented the students' ability in the pre-test. The $X$ represented the implementation of the English teaching material developed through the Total Physical Response (TPR) learning model and character-based education in learning process. While the second $\mathrm{O}$ represented students' ability in the post-test after implemented the English teaching material developed.

\subsection{Research Instrument and Data Analysis Technique}

There were two instruments used, English test and observation, in deternining the effectiveness of the English teaching material developed. English test was used to examine the students' ability before and after the implementation of English teaching materials. Meanwhile, the observation was employed to describe 
students' character improvement. In analyzing the data to examine students' English ability, N-Gain calculation was employed. It can be seen in the equation below [9]

$\{g\}=\frac{S f-S i}{S \max -S i}$

Equation (1) showed that $\{\mathrm{g}\}$ is the $\mathrm{N}$-gain score, $S f$ is the post-test score while $S i$ is the pre-test score. Smax is the maximum score the students could achieve in the test. $\mathrm{N}$-gain score is described based the criteria in Table 1 .

Table 1. N-Gain score criteria

\begin{tabular}{ll}
\hline N-Gain Score Criteria & Predicate \\
\hline$\{\mathrm{g}\}>0,7$ & High \\
$0,3<\{\mathrm{g}\}<0,7$ & Moderate \\
$\{\mathrm{g}\}<0$ & Low \\
\hline
\end{tabular}

The N-Gain score indicates the improvement of students' ability before and after the implementation of English teaching material using the TPR and based character education. The gradation of $\mathrm{N}$-Gain score was showed in the Table 1 to determine the subject performances which were varies from high to low criterias.

Furthermore, in analyzing students' character, the data analysis was ilustrated in Equation (2)

$P=\frac{A}{n} \times 100 \%$

In equation (2), $P$ represented the calculation of percentage, $A$ defined the number of students' activities which represented character were observed during the learning process, and $n$ represented the total number of the students in the class. The indicators of students' character improvement were $70 \%$ of students done the class activities.

\section{RESULTS AND DISCUSSION}

The implementation of the English teaching material using Total Physical Response (TPR) learning model and based character education was carried out in four meetings. The result of students' achievement in English learning was presented in Table 2.

Table 2. Students' English achievement

\begin{tabular}{lllll}
\hline Test & $\begin{array}{l}\text { Total } \\
\text { Students }\end{array}$ & Mean & $\begin{array}{l}\text { Standard } \\
\text { Error }\end{array}$ & $\begin{array}{l}\text { Standard } \\
\text { Deviation }\end{array}$ \\
\hline Pretest & 20 & 63.00 & 1.67 & 7.30 \\
Posttest & 20 & 81.00 & 1.65 & 7.23 \\
\hline
\end{tabular}

The table 2 showed that the pre-test's mean score was 63.00 with standard error is 1.67 and the standard deviation was 7.30. Meanwhile, the post-test mean score was 81.00 with standard error was 1.65 and the standard deviation was 7.23. Jugding from the mean score, it can be seen that students' achievement in learning English improved by using English teaching material using the TPR and based character education. It was in line with the study which examined 15 students' English ability which improved after using the TPR as a learning model [10]. The N-Gain calculation of students' achievement in English learning can be seen in Table 3;

Table 3. The percentage of students' achievement based

\begin{tabular}{lll}
\multicolumn{3}{c}{ N-gain criteria } \\
\hline $\begin{array}{l}\text { Score } \\
\text { range }\end{array}$ & $\begin{array}{l}\text { Percentage } \\
(\%)\end{array}$ & Predicate \\
\hline $\mathrm{g}>0.7$ & 10 & High \\
$0.3<\mathrm{g}>0.7$ & 80 & Moderate \\
$\mathrm{g}<0.3$ & 10 & Low \\
\hline
\end{tabular}

Based Table 3, the students' achievement in learning English was in the moderate criteria which gained percentage was $80 \%$ while both high and low criteria gained $10 \%$ percentage. It meant that the English teaching material developed through the TPR and character-based education contributed to students' ability was moderate ability. Meanwhile the percentage of students' achievement categorize as high percentage was as many as low percentage.

English teaching combined with the TPR learning model was compatible and supportive in achieving students' learning abilities. A study examined 150 students and 26 teachers showed that the TPR model was benefit to the students' achievement in learning English vocabulary for beginners [11].

Moreover, the students' character improvement were presented in Table 4 below;

Table 4. The percentage of students' character achievement

\begin{tabular}{lllll}
\hline Character & \multicolumn{3}{c}{ Week } \\
\hline & I $(\%)$ & II $(\%)$ & III $(\%)$ & $\begin{array}{l}\text { Mean } \\
\text { Score }\end{array}$ \\
\hline Confident & 55 & 73 & 85 & 71 \\
Responsible & 63 & 70 & 83 & 73 \\
Hardwork & 65 & 75 & 90 & 77 \\
Creative & 40 & 55 & 65 & 53
\end{tabular}

Table 4 shows that students' character achievement improved at every meeting. The mean score for three of four characters are above $70 \%$ which means students' 
character is changing to be better after implementing the English teaching material using the Total Physical Response (TPR) learning model and based character education. A study shows that the TPR is effective to encourage the students' who are unwilling to speak which is in line with the result findings of this research where the TPR can improve students' confident [12]. Moreover, students' character in responsible and hardwork also improved as the mean score is $73 \%$ and $77 \%$. However, this teaching material does not affect students' improvement on creative character since the TPR learning model is a repetitive vocabulary learning [13].

The results of the $\mathrm{N}$-gain calculation and the learning process observation explain the implementation of the English teaching material provides an improvement to students' hard skills and soft skills. Students'hard skills improved because the English teaching material is combined with the TPR learning model. It is a model which can encourage students' to learn foreign language naturally because it stimulates language comprehension with motoric activities [14]. In teaching foreign language to young learners, it is important to construct the learning situation which has delight atmosphere and as naturally as possible in order to establish a situation where children learn a foreign language like learning their mother tongue [15][16].

Furthermore, this English teaching material implermentation also encourages students to be active, responsible, and confident in the learning process. They learn to cooperate with others, perform in front of the class, and do discussion in pairs. These are the values of character education which are integrated in the learning process of English. The design of this English teaching material included image illustration and exercisses which packaged in attractive form in order to attract students' interest so they are excited and the English learning process in fun.

\section{CONCLUSION}

The result of this research showed that the students' English ability achievement was moderate. Furthermore, the students' character achievement achieve high percentage in almost all aspects. Thus, it can be concluded that the learning process by using English teaching material based character education and using Total Physical Response (TPR) learning model is effective to improve both hard skill and soft skills for students at fifth-grade of one private elementary schools in Pariaman City.

\section{AUTHORS' CONTRIBUTIONS}

The authors' roles in this research are as researcher and observer.

\section{ACKNOWLEDGMENTS}

The researchers expressed their gratitude to the Directorate of Research Empowerment and Development of the Indonesian Ministry of Research Technology and Higher Education (Kemendikbudristek) who had provided the grant in finishing this research. We also express our great thank to the Head of a private elementary school in Pariaman for giving a permit in conducting this research.

\section{REFERENCES}

[1] Kaltsum, H. U., \& Habiby, W. N. The Implementation of Local Content Curriculum of English for Elementary School in Surakarta, Indonesia. In 1st Borobudur International Symposium on Humanities, Economics and Social Sciences, 2020. 936-940.

[2] Farikah, F. Implementasi Model Child Friendly School (CFS) Dalam Pembelajaran Bahasa Inggris (Studi Kasus Di Sd Negeri Secang 1 Kabupaten Magelang). Prosiding Seminar Nasional "Optimalisasi Peran Pendidikan Dalam Membangun Karakter Anak Untuk Menyongsong Generasi Emas Indonesia,” 2016., 546-549.

[3] Maryono, "The Implementation of Schools' Policy in the Development of the Local Content Curriculum in Primary Schools in Pacitan, Indonesia," Educ. Res. Rev., 2016, vol. 11, no. 8, pp. 891-906.

[4] Zein, M. S. "Elementary English education in Indonesia: Policy developments, current practices, and future prospects," English Today, Mar. 2017. vol. 33, no. 01, pp. 53-59,

[5] Alwasilah, C. Policy On Foreign Language Education In Indonesia. International Journal of Education, 2013, 7(1), 1-19.

[6] Shi, T. A Study of the TPR Method in the Teaching of English to Primary School Students. 
Theory and Practice in Language Studies, 2018, 8(8), 1087. https://doi.org/10.17507/tpls.0808.25

[7] Wandasari, Y. Implementasi Gerakan Literasi Sekolah (GLS) Sebagai Pembentuk Pendidikan Berkarakter. JMKSP (Jurnal Manajemen, Kepemimpinan, Dan Supervisi Pendidikan), 2017, 2(2), 325-342.

[8] Ary, D., Jacobs, L. C., Irvine, C. K. S., \& Walker, D. Introduction to Research in Education. Cengage Learning. 2018.

[9] Nissen, J. M., Talbot, R. M., Thompson, A. N., \& Van Dusen, B. A comparison of Hake's g and Cohen's $d$ for analyzing gains on concept inventories. Physical Review Physics Education Research, 2018, 14(1), 010115. https://doi.org/10.1103/PhysRevPhysEducRes.14.0 10115

[10] Fadlan, A., Ridwan, R., Nopriansyah, U., \& Nurfaizah, N. Penerapan Metode TPR (Total Physical Respone) Dalam Pembelajaran Bahasa Inggris Anak Usia Dini. Al-Athfaal: Jurnal Ilmiah Pendidikan Anak Usia Dini, 2021, 4(1), 137-151. https://doi.org/10.24042/ajipaud.v4i1.8619

[11] Hounhanou, A. J. V. Promoting TPR (Total Physical Response) Method in Teaching Vocabulary for EFL Beginners in Benin Secondary Schools. International Journal of Applied Linguistics and English Literature, 2020, 9(6), 2331. https://doi.org/10.7575/aiac.ijalel.v.9n.6p.23

[12] Amano, J. Variable Effects of Total Physical Response in Reducing EFL Students' Unwillingness to Speak English. LET Journal of Central Japan, 2017, 28, 13-28. https://doi.org/10.20656/letcj.28.0_13

[13] Yusuf, Q., Asyik, A. G., Yusuf, Y. Q., \& Rusdi, L.. "Listen, Do, Repeat, Understand and Remember": Teaching English to Very Young Children in Aceh. Iranian Journal of Language Teaching Research, 2017, 5(2), 113-132.

[14] Febriyanti, R. H. Pelatihan Penggunaan Metode Total Physical Response dan Natural Approach Dalam Pengajaran Bahasa Inggris di Lembaga Pendidikan Active English Course. Faktor: Jurnal Ilmiah Kependidikan, 2016, 3(1), 47-52. https://doi.org/10.30998/fjik.v3i1.659
[15]Garton, S., \& Copland, F. The Routledge Handbook of Teaching English to Young Learners. Routledge. 2018.

[16]Gungor, M. N. Turkish pre-service teachers' reflective practices in teaching English to young learners. Australian Journal of Teacher Education (Online), 2016, 41(2), 137-151. https://doi.org/10.3316/ielapa.855872398752970 